\title{
Enterprise Transformation as Coordination Game: The Leadership Challenge*
}

\author{
Klaus E. Meyer ${ }^{* *}$
}

Empirical evidence, especially in case studies, shows that individual leaders often have a crucial role in successful enterprise transformation in transition economies. Conventional economic analysis of corporate governance alone cannot explain this role of leadership. In this theoretical paper I use coordination games to analyse transitions from one equilibrium to another. I argue that the creation of common knowledge among stakeholders by a leader allows firms to overcome coordination failures. This is crucial for enterprise transformation because of the multiplicity of stakeholders who need to coordinate their action to implement radical organizational change.

Empirische Daten, besonders bei Fallstudien, zeigen, dass individuelle Personen bei der Führung von Unternehmen im Wandel oft eine zentrale Rolle einnehmen. Eine konventionelle ökonomische Analyse der Unternehmensführung allein kann diese Rolle von einzelnen Führungspersönlichkeiten nicht erklären. In dieser theoretischen Untersuchung werden Koordinationsspiele zur Analyse von Übergängen von einem Gleichgewichtszustand in einen anderen benutzt. Es wird dafür argumentiert, dass die Schaffung von gemeinsamem Wissen unter den Stakeholdern einer Unternehmung durch eine Führungspersönlichkeit den Unternehmen die Möglichkeit gibt, Koordinationsfehler zu vermeiden. Dabei handelt es sich um einen äußerst wichtigen Aspekt, da es bei der Umsetzung radikaler Veränderungen der Organisation darauf ankommt, den unterschiedlichen Koordinationsaspekten der Vielzahl von Stakeholdern Rechnung zu tragen.

\footnotetext{
* manuscript received: 06.11.2000, accepted: 09.01.2001;

${ }^{* *}$ Klaus E. Meyer (London) is research professor at the Center for East European Studies at the Copenhagen Business School. His research focusses on foreign direct investment and enterprise transformation in transition and emerging economies.
} 


\section{Introduction}

Widespread malaise characterizes the progress of enterprise transformation (ET) in Eastern Europe (e.g. Nellis 1999). Scholarly research has focused on methods of privatization, and on the implications of the new ownership structures. The dominant line of inquiry has been the analysis of incentives faced by managers under different arrangements of corporate governance, using principal agenttheory. Yet few performance differences can be explained by the differences in ownership and governance structure, especially in the former Soviet Union (Estrin and Wright 1999). This led to a sense of dissatisfaction with agencybased perspective as main avenue for analysing ET (Stiglitz 1999, Kogut and Zander 2001) and the search for alternative theoretical approaches (e.g. Spicer, et al. 2000, Uhlenbruck et al. 2000).

Case evidence points to an aspect scarcely considered in the literature: the role of individuals at the helm of the enterprise. This paper presents a theoretical logic that can explain the progress in ET, independent of the principal-agent logic of corporate governance that has dominated the transition literature so far. Successful ET requires to solve major coordination games. Yet coordination games frequently fail, even in simple experimental settings (Ochs 1995). A mechanism is thus needed that induces agents to choose routines that provide the mutually best outcome. Leaders can resolve coordination games not only by changing the structure of the game but by creating 'common knowledge' among agents on which routines shall be pursued in the future. They can therefore overcome the extensive coordination problems faced by firms during ET.

The next section introduces the coordination problems of economic transition, which are analysed in a game-theoretic perspective in section three. I focus on coordination problems as such, and thus abstract from potential incentive conflicts that may further complicate the situation. Section four concludes with implications for policy and further research.

\section{Enterprise Transformation as a Coordination Problem}

ET requires a radical change of the enterprise changing not only the production process but also the nature of its external relations and its 'inner logic'(Newmann 2000, Meyer 1998). Enterprises are complex social organizations that bring together a large number of individuals with very diverse and potentially conflicting interests. This holds especially true in enterprises undergoing the transformation from plan to market as not only internal but also many external stakeholders aim to influence its restructuring strategy (Berglöf and v.Thadden 1999, Mygind 1999). The success or failure of ET depends on the combined effort of inter alia,

- employees, who are a very heterogeneous group, and may have ownership rights too, 
- shareholders (after privatization), who may be dispersed, or linked to the firm in ways other than ownership,

- providers of non-equity capital,

- providers of technological and managerial knowledge,

- suppliers and customers, some related by a long-term cooperation,

- government bureaucrats and politicians, whose support is necessary not only in firms in state-ownership, but also for private firms with a restructuring plan that depends on the regulatory environment, or direct or indirect financial support.

Case research on privatization and restructuring provides plenty of evidence of ET being derailed by conflicts between multiple agents. In Hungary, AntalMokos (1998) observed that internal 'politicking' between different groups and the involvement of political interest groups has prevented the implementation of a coherent strategy. In Poland, the need to obtain support from employees and their elected worker council has inhibited many restructuring plans (Carlin et al. 1995, Brada and Singh 1999, B $\square \mathrm{k}$ and Kulawcuk 1998). In the Czech Republic, complex ownership structures require the coordination of interdependent firms and banks (e.g. Spicer et al. 2000). In the Baltic states and Russia, insiderownership necessitates building broad support within the organization for major strategic decisions. Throughout the region, conflicts between multiple stakeholders, or with individuals holding restitution claims, delayed substantive investment in restructuring.

Scholars have recognized coordination problems as a major cause of market failure during transition. Swaan (1997) argues that several types of transaction costs are involved in establishing new relationships because agents have few contacts and reference points for future business. Agents not only have to engage in search and negotiations, but they have to develop new competences required for market-based transactions. This transaction problem has been formalized by Blanchard and Kremer (1997) who show that the output drop in transition economies can be largely explained by coordination failure, which they model based on information asymmetries. Roland and Verdier (1999) present a similar model based on the search costs of finding business partners. Moreover, the lack of legal infrastructure to enforce contracts and property rights makes market solutions to many coordination problems particularly costly. However, scholars have not yet addressed coordination failures within enterprises.

Principal-agent models cannot be applied if complex bargaining situations involve multiple diverse agents related to any firm, because agency relationships are poorly defined, or non-existing. The policy advice of principal agency theorists thus focusses on the creation of clear governance structures 
that define agency relationships. Yet this is easier said then done. Formalizing the negotiation setting

Table 1: Examples of former state firms that successfully transformed themselves

\begin{tabular}{|c|c|c|}
\hline Case & Sources & Success factors \\
\hline $\begin{array}{l}\text { Szczecin Shipyard } \\
\text { (shipyard, Poland) }\end{array}$ & $\begin{array}{l}\text { Johnson and } \\
\text { Loveman (1996), } \\
\text { Johnson et al. } \\
\text { (1996) }\end{array}$ & $\begin{array}{l}\text { * Leadership: the chosen new manager came with a } \\
\text { comprehensive restructuring plan. } \\
\text { * Consensus of key stakeholders, especially workers and } \\
\text { creditors, was gained by making a persuasive case that a } \\
\text { smaller viable shipyard was preferable to a bankrupt } \\
\text { shipyard; hard budget constraints. }\end{array}$ \\
\hline $\begin{array}{l}\text { Jenaglas (precision } \\
\text { optical instruments, } \\
\text { East Germany) }\end{array}$ & $\begin{array}{l}\text { Peng }(2000) \text {, } \\
\text { Kogut and Zander } \\
(2001)\end{array}$ & $\begin{array}{l}\text { * Visionary Western management team, pushing through } \\
\text { radical restructuring, even if opposed by local interest } \\
\text { groups. } \\
\text { * World-leading technological competence, financial } \\
\text { resources from government support. }\end{array}$ \\
\hline $\begin{array}{l}\text { Veba Broumov } \\
\text { (textile, Czech } \\
\text { Republic) }\end{array}$ & $\begin{array}{l}\text { Newman and } \\
\text { Nollen (1998), } \\
\text { Matesova (1999) }\end{array}$ & $\begin{array}{l}\text { * Leadership, esp. in terms of strategic thinking, } \\
\text { decisiveness and initiative, and cost awareness. } \\
\text { * Continuous learning from customer contact and } \\
\text { competition, and from Dutch consultants. }\end{array}$ \\
\hline $\begin{array}{l}\text { Graboplast (textile, } \\
\text { Hungary) }\end{array}$ & $\begin{array}{l}\text { Grayson and } \\
\text { Bodily (1996) }\end{array}$ & $\begin{array}{l}\text { * "The most important element which made this } \\
\text { company turn around is the attitude of the CEO ... the } \\
\text { manager's support to bring in outside consultants to cut } \\
\text { the fat around the company." } \\
\text { * cost leadership and high efficiency. }\end{array}$ \\
\hline $\begin{array}{l}\text { Revda (lighting, } \\
\text { Russia) }\end{array}$ & $\begin{array}{l}\text { Gallagher and } \\
\text { Scott (1996) }\end{array}$ & $\begin{array}{l}\text { * Entrepreneurial leadership: innovative, decision maker, } \\
\text { visionary, creative. } \\
\text { * "Changing the cultural norms of non-acceptance of } \\
\text { responsibility, the desire for certainty and the reticence } \\
\text { to cope with increased levels of ambiguity." }\end{array}$ \\
\hline $\begin{array}{l}\text { H5 (chemical } \\
\text { engineering, } \\
\text { Hungary) }\end{array}$ & Lieb-Dóczy (2000) & $\begin{array}{l}\text { * The end of political interference and new management } \\
\text { team pursuing socially responsible restructuring. } \\
\text { * Resources: cheap inputs based on long-term supply } \\
\text { contracts, strong technology, and development of related } \\
\text { firms in the vicinity. }\end{array}$ \\
\hline
\end{tabular}


Note: The firms are successful examples of former state-owned firms that are not foreign-investment firms, and not newly established firms. The success factors are based on the original case authors' assessment.

in a broader game-theoretic model is complex and, while a Nash-equilibrium may exist, finding it may take far longer than the pressures of competitive markets permit.

Case evidence shows, however, that some firms have restructured successful despite the involvement of multiple stakeholders. We have collected in-depth case studies ${ }^{1}$ on ET and identified those positive outliers that, according to the respective authors, excel in terms of performance (table 1). These firms developed a pro-active strategy pursuing a niche market strategy and/or acquiring complementary assets internationally. As would be expected, they have some valuable technological assets and a workable governance structure with hard budget constraints.

Yet in addition, the authors in most cases of outstanding performance emphasize the role and personality of the individual, or the management team, leading the enterprise. Johnson and Loveman (1996) compare the shipyards in Szczecin and Gdansk, and attribute the pro-active restructuring and superior performance in Szczecin to the role of Krystof Piotrowski as CEO. He managed to negotiate a debt restructuring with a diverse group of creditors and, and at the same time, used his high standing and credibility to persuade union members to accept large layoffs for the long-term benefit of the firm. Entrepreneurs like Piotrowski are not just administrative heads, but managers, or, in other words, leaders. They manage the formidable challenges of both creating and implementing new corporate strategies.

The importance of bringing in new managers, rather than creating stronger incentives for incumbents has also been highlighted in empirical studies. Barberis et al. (1996), who analyse 452 shops in Russia, find that change of the manager stimulates restructuring. Hence they argue that "restructuring requires new people, who have new skills more suitable to a market economy", and that "equity incentives for old people might not be particularly effective in bringing about significant change" (1996:488). Also, Claessens and Djankov (1998) find that performance in the Czech Republic is improved by changing managers, but not by providing managers with incentives in form of equity stakes. All their performance indicators are negatively correlated with the length of tenure of the general manager of the firm, but positively correlated to the external recruitment of managers. Yet studies do not explain what the new managers contribute, that incumbents could not.

\footnotetext{
${ }^{1}$ The database containing some 300 case studies is held jointly by Klaus Meyer (Copenhagen Business School) and Klaus Uhlenbruck (Texas A\&M University).
} 
What distinguishes a business leaders in a market economy from an administrative head of a business unit in a central plan regime? First, they have to develop a corporate strategy. They have to identify business opportunities through continuous analysis of the business environment and of the position of the firm and its resources. On this basis, strategies have to be developed, assessed, and adjusted, which requires both analytical skills and creativity. The strategy may be expressed in a business plan that shows how the firm shall be repositioned. It establishes how the resources of the firm shall be combined and organized in innovative ways to create a competitive edge in whatever markets the firm chooses to be in. Among the infinite number of possible restructuring strategies, the leader has to identify one path that the enterprise shall pursue.

Secondly, the strategy has to be implemented. This requires coordination of the activity of all the stakeholders that provide resources for the operations of the firm. They, or at least a critical mass of them, have to be convinced of the path to pursue. An important step in doing so is to create appropriate incentive structures for the individual agents. Notably, those who would loose out, may have to be compensated by side payments. If the incentives faced by individual agents are not compatible, e.g. due to prisoners' dilemma type problems, noncooperative games can emerge. To resolve such incentive conflicts, (Dewatripont and Roland (1995) propose sequential coalition building. This has been essential at several stages of the Russian reform process as stakeholders have been expropriated or co-opted (Shleifer and Treisman 1999). Yet such an approach can lead to concessions to powerful stakeholders that undermine the coherence of the overall reform strategy (see Goldberg and Freinkman 2000 for examples).

Even if all stakeholders would become better off with the new strategy, they may fail to coordinate their individual routines accordingly. ${ }^{2}$ They may face cognitive barriers to understanding the structure of the game and other players' likely actions. Leadership can overcome the coordination failure and bring all members of an organization on a common path of change - by creating the expectation that everyone else is pursuing the same path (Foss 2001). I analyse a 'coordination game' to demonstrate this role of leadership. These may appear simplistic relative to other games, yet they provide a powerful tool to analyse organizational realities, and the emergence or design of institutions in particular (Camerer and Knez 1994, Calvert 1995). ${ }^{3}$ To focus the argument, I thus assume henceforth that incentive-compatibility problems have been resolved.

\footnotetext{
${ }^{2}$ I adapt the following terminology: strategy refers to the action of the firm, and routine to the actions by individuals within the firm.

${ }^{3}$ For a recent review of coordination games, formal models and macroeconomic applications see Cooper (1999).
} 


\section{A Coordination Game Analysis}

Transition can be depicted as moving socialist firms from a low-level equilibrium to a higher level one. It should, in theory, be obvious to all agents involved that they can achieve higher returns for their firms and for themselves personally, if they change their individual routines to market-based ones. Yet why are they not changing?

Figure 1 illustrates the dilemma of agents in a firm undergoing deep restructuring as a 'coordination game' (cf. Farrell 1988, Colman 1997). Two players, 1 and 2 both face a choice between two routines A and B. The pay-off matrix appears to suggest, at first sight, that both players ought to play strategy $\mathrm{B}$, and collect the pay-off of two units each.

Figure 1: A coordination game

\begin{tabular}{|c|c|c|c|}
\cline { 3 - 4 } \multicolumn{2}{c|}{} & \multicolumn{2}{|c|}{ Player 2 } \\
\cline { 3 - 4 } \multicolumn{2}{c|}{} & A & B \\
\hline \multirow{2}{*}{ Player 1 } & A & $(1,1)$ & $(0,0)$ \\
\cline { 2 - 4 } & B & $(0,0)$ & $(2,2)$ \\
\hline
\end{tabular}

Note: in the initial situation, all agents play routine $A$ (shaded area).

Yet, suppose the two players have played routine A for the past forty years, currently earning pay-offs of $(1,1)$. They may become aware that due to changes in the environment, routine B becomes feasible, but they individually have incentives to stay with strategy A, if expectations over other player's strategy are formed based on past behaviour. No one has incentives to divert from (A,A), which is a Nash-equilibrium. Such a backward formation of expectations is commonly assumed in adaptive learning and evolutionary models of game theory (e.g. Fudenberg and Kreps 1993), and fairly realistic unless potential losses are small. Experiments of repeated games have shown strong path dependency: "learning commonly yields convergence to an equilibrium in the stage game, but the outcome is frequently history-dependent, and the effects of strategic uncertainty may persist long after it has been eliminated by learning" (Crawford 1997: 235, emphasis added).

A move to the higher level equilibrium will occur if both players believe that the other will play the new routines. The switch to the higher level-equilibrium requires players to change their beliefs about the other player. ${ }^{4}$ Recognizing the

\footnotetext{
${ }^{4}$ There has not been any systematic experimental research on how shocks that change the payoff influence the likelihood of observing convergence to an equilibrium, let alone a specific equilibrium (Ochs 1995). The outcome is likely to be highly sensitive to how the information about the changes reaches the players.
} 
new strategic option, players do not know if the other player has the same information. Neither do they know when the other player will move to routine B. The agents will only act if they share 'common knowledge' (Lewis 1969, Geanakoplos 1992) on the structure of the new game, and when the switch to the new routines is to occur. Common knowledge refers to a situation where A knows that B knows that A knows that B knows, and so on, i.e. all agents know that others also share the knowledge, inclusive the fact that everyone else knows it too. Without common knowledge, on both the new pay-off structure and the timing of the switch, the higher-level Nash-equilibrium may never be reached. $^{5}$

Let us take the timing issue first. In our simple example, the coordination can be achieved through modifications in the assumptions, e.g. by allowing pre-play communication (Farrell 1988, Myerson 1989, Kim and Sobel 1995). Suppose, one player is appointed leader allowing her $^{6}$ to make (non-committing) announcements about the strategy. This suffices for her to lead the game to a Pareto-optimal Nash-equilibrium if she announces a strategy, from which she has no incentives to divert. Communicating it, she creates a focal point that becomes common knowledge. Experimental studies show that one-sided announcements increase the likelihood of reaching the efficient outcome substantially (Cooper et al. 1994). ${ }^{7}$

Moreover, a leader can overcome coordination failure by creating common knowledge about the strategy to be pursued (Foss 2001). She takes the necessary decisions on corporate strategy and the future role of the agents. Since the strategy is new - strategy formulation is a creative act - we cannot assume, as most game-theoretic analysis does, that the structure of the new game is common knowledge. Two-person two-routine games are very simplifying approximations of the real world, where games are large, with imperfect recall, state-contingent uncertainty etc. Agents are likely to have

${ }^{5}$ Dependent on the structure of the game, it may suffice that agents share common beliefs rather than common knowledge (Monderer and Samet 1989). Agents' successful coordination of routines depends on the beliefs they hold about each others beliefs. The more well-founded these beliefs are, the better they are able to coordinate (Foss 2001). On the other hand, in certain situations, even almost common knowledge may not suffice to coordinate on the most efficient outcome: Suppose coordination occurs via e-mail, yet a message gets lost. As agents do not know whose message got lost, they may fail to coordinate on the most preferable outcome (Rubinstein 1989).

${ }^{6}$ Analogous to the convention in the principal agent literature, I refer to the leader as she, and to the players (agents, employees, stakeholders) as he.

${ }^{7}$ The situation is more complex if both players are permitted to send messages to each other before the game. If played infinitely, they too reach the superior Nash equilibrium eventually (Kim and Sobel 1995). Yet, as shown in the experiments by Cooper et al. (1994), coordination failure in the initial stages of the game is likely. 
incomplete information (or, especially in a transition context, none at all) about other players and available strategies (Calvert 1995, Foss 2001). In other words, common knowledge about the game has to be created. Strategic decisions have to be communicated to all stakeholders in such ways that everyone knows that this knowledge is shared with all other relevant parties.

Thus the leader can facilitate the move to a higher level equilibrium by coordinating the complementary actions of agents through designing incentive compatible routines and by creating common knowledge concerning their implementation. The techniques employed by leaders to create common knowledge may be culturally bound. Western business leaders and scholars stress the need to create a tangible vision to focus the organisation's activities and learning (e.g. Ireland and Hitt 1999, Finkelstein and Hambrick 1996). A shared vision implies common knowledge on the organisation's objectives. It may be created through, for example, public speeches to communicate in person and simultaneously to many agents, who thus know that they share the new knowledge with everyone else who also attended the event. Increasingly, videoconferencing and e-mailing to 'everyone in group $\mathrm{x}$ ' provide alternative, though imperfect, means.

Participatory decision processes that involve public debate on the underlying issues facilitate the creation of common knowledge on challenges facing the organization, and alternative strategic responses (though not the decision itself). In Russia, Vlachoutsicos (1998) observed a traditional participatory process, which ends with a decision that is taken at the top and communicated 'topdown'. This process, even if ritualized and with little impact on the actual decision in socialist and post-socialist firms, provides an important means to share knowledge. Moreover, it informs the leader where she has to fill in gaps of the common knowledge of the organization.

Figure 1 depicts the simplest form of a coordination game. Yet, the real world is more complex, even without conflicting interests. Complexity, however, reinforces the inertia, i.e. the stability of the inferior Nash-equilibrium. Let us consider some related challenges facing enterprises during transformation using coordination games as framework. Small variations can make the game a more appropriate reflection of the situation of firms facing ET:

- Suppose, agents have to invest in human capital, a sunk cost, to be able to shift their routines. This sunk cost may moreover be higher the earlier a player changes his routine.

- Suppose, stakeholders face several new strategies B, C, D, ... that yield higher returns only if all pursue the same routine, but lower returns 
otherwise. The game has multiple Pareto-ranked equilibria, but no selection mechanism to choose among them, ${ }^{8}$ or

- Suppose, the new routines require considerable learning in the organization, as is common in the case of ET (e.g. Child and Czegledy 1996). All agents have to be educated how to implement their new routines. This may involve fundamental changes, e.g. in communication patterns or in attitudes towards quality and efficiency. Agents aiming for a new routine $\mathrm{B}$ may thus erroneously play routine $\mathrm{B}^{*}$, which results in an inferior outcome. Figure 2 illustrates such a situation, making the positive assumption that one player's failure does not affect the other player's pay-off. Even so, it makes a change of routines more risky, and thus reinforces inertia.

Under less favourable assumptions, the coordination challenge becomes even more complex: If the higher level pay-off is dependent on both players playing B correctly, then the choice of action depends additionally on each players' belief of the other player knowing how to play B. In addition to training, effective communication between the participants about their capabilities, facilitated by the leader, is essential to solving this coordination game.

Figure 2: Coordination game with a faulty strategy

\begin{tabular}{|c|c|c|c|c|}
\cline { 3 - 5 } \multicolumn{2}{c|}{} & \multicolumn{3}{c|}{ Player 2 } \\
\cline { 3 - 5 } \multicolumn{2}{c|}{} & A & B & B* \\
\hline \multirow{3}{*}{ Player 1 } & A & $(1,1)$ & $(0,0)$ & $(0,0)$ \\
\cline { 2 - 5 } & B & $(0,0)$ & $(2,2)$ & $(2,0)$ \\
\cline { 2 - 5 } & B* & $(0,0)$ & $(0,2)$ & $(0,0)$ \\
\hline
\end{tabular}

Note: in the initial situation, all agents play routine $A$ (shaded area).

Furthermore, ET requires the coordination of a large number of stakeholders. Theoretical and empirical research suggests that with the number of players, the probabilty of coordination failure increases. This is caused by the fact that in most of the games analyzed, defection of a single agent significantly reduces returns for all others. Theoretical models show such failure for instance if mutations or inertia influence the selection of routines (Cooper 1999:14). Experimental research mostly uses 'weakest-link games', and finds that groups

${ }^{8}$ This situation is similar to 'stag hunt games' where routines are associated with different efforts and returns depend on the lowest effort by any player. Experiments have shown that, although groups often reach an equilibrium, failure to coordinate on the Pareto-optimal equilibrium was observed in several of the experiments reviewed by Crawford (1997) and Ochs (1995). 
of 10 persons or more mostly fail to coordinate on the optimal equilibrium (e.g. Camerer and Knez 1994).

However, such strict necessity of all agents co-operating is not an appropriate reflection of ET, which is the focus of this analysis. It is more fitting to assume that superior outcome is reached if many but not necessarily all agents cooperate. Figure 3 considers a game where many players need to coordinate their shift from an established but inferior routine 'old' to a superior one called 'new'. The new routine yields a higher pay-off if, and only if, a substantial proportion of the agents shift to the new regime. If only a small number of agents change, everyone may in fact become worse off. This leads to a critical mass problem: it is necessary that a sufficiently large number of agents believe that a critical number of others will shift to the new routine. This is illustrated in the dynamic coordination game with ten agents in Figure 3:

Figure 3: Coordination Game with a Critical Mass Payoff for players playing 'old' and 'new',respectively.

\begin{tabular}{|l|c|c|c|c|c|c|c|c|c|c|c|}
\cline { 2 - 14 } \multicolumn{1}{c|}{} & \multicolumn{10}{c|}{ number of agents playing 'new' } \\
\cline { 2 - 14 } \multicolumn{1}{c|}{} & 0 & 1 & 2 & 3 & 4 & 5 & 6 & 7 & 8 & 9 & 10 \\
\hline old routine & 3 & 2 & 2 & 2 & 2 & 1 & 1 & 1 & 0 & 0 & n.a. \\
\hline new routine & n.a. & 0 & 1 & 1 & 2 & 2 & 3 & 4 & 4 & 5 & 6 \\
\hline
\end{tabular}

Note: Individual payoff for players playing old / new routine, dependent on the number of players that switch to the new routine. Initially, all agents play the old routine (shaded area).

In the initial situation, all ten players follow the old routine and collect a payoff of 3 , as illustrated by the shaded area. If some agents change to the new routine, this will reduce the benefits for those staying with the old routine. If all ten switch to the new routine, they will all be better off. However, the initial position is a stable Nash-equilibrium: with adaptive expectations (based on other agents' past behaviour), no agent, not even a pair of agents, has an incentive to change. It requires a coordination of - in the example - at least six agents to play 'new' to create a situation where playing 'new' yields at least equal return of 3 units.

Figure 4 considers a general case of this multi-person coordination game. Agents choose between staying with their old routine and switching to the new one based on their expected return from either. This, however, depends on their beliefs concerning other players behaviour. If the agent believes that at least $\boldsymbol{a}$ agents will switch, he will do likewise - even if the new return is below the payoff in the previous period. Thus, $\boldsymbol{a}$ is the critical mass (or 4 players in the example of Figure 3). 
Considering the evolutionary dynamics of the game, it has three equilibria, of which two are stable. In repeated rounds of this game, with expectations formed based on past outcomes, the dynamics of the game will lead to a convergence to an equilibrium where all agents play the same strategy, $\mathrm{E}^{\mathrm{o}}$ or $\mathrm{E}^{\mathrm{n}}$, though it may temporarily rest at the inferior unstable equilibrium $\mathrm{E}^{\mathrm{a}}$. If at least $\boldsymbol{a}+\boldsymbol{1}$ shift to 'new', the game converges to the new equilibrium $\mathrm{E}^{\mathrm{n}}$. If less than $\boldsymbol{a}$ agents shift to the new regime, the dynamics of a repeated game will lead to a return to the original, low-level equilibrium $\mathrm{E}^{\mathrm{o}}$.

Figure 4: Coordination Game with critical mass Payoff functions for agents using 'new' and 'old' routines

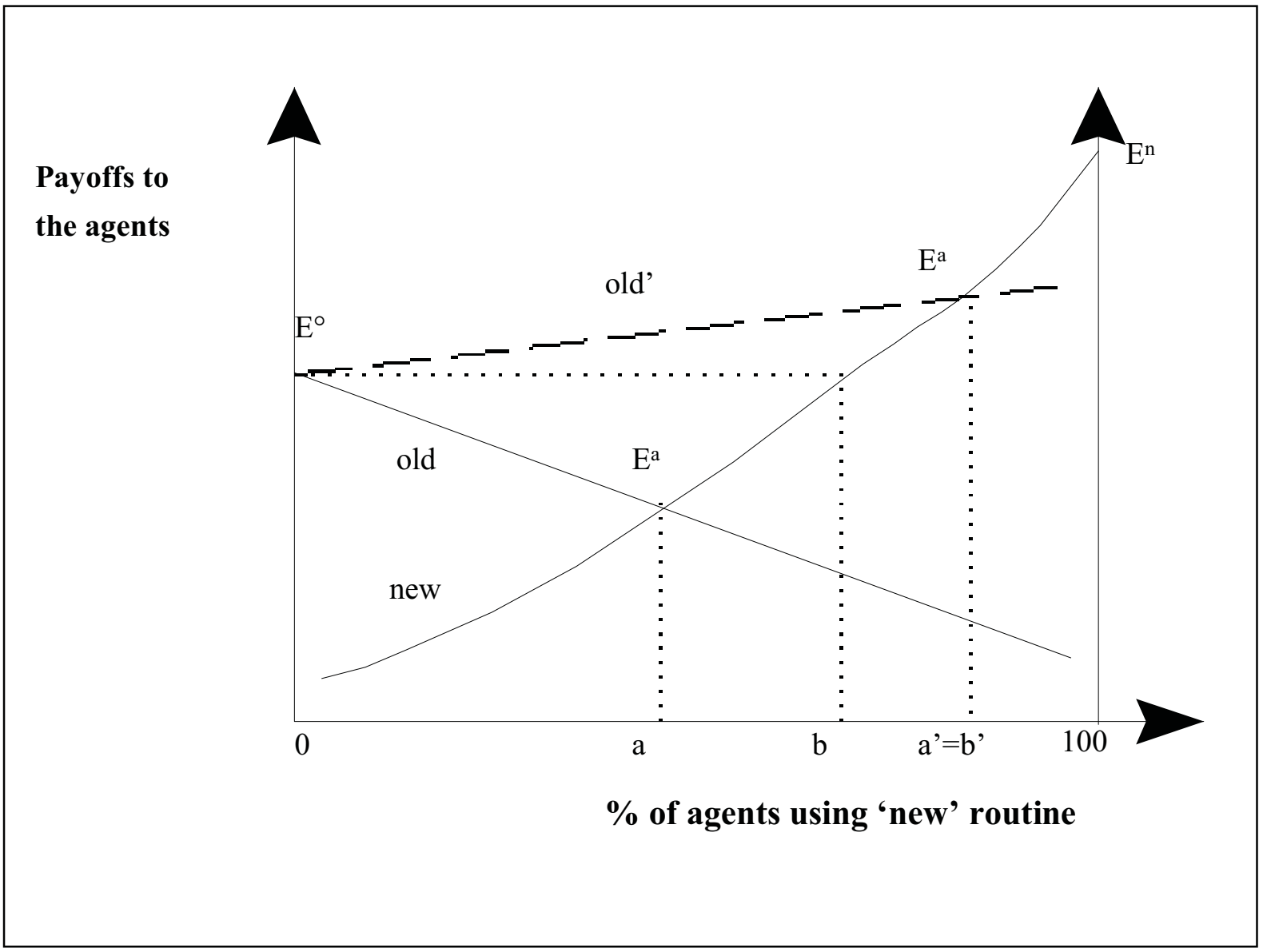

The leader thus does not need to convince all stakeholders to adopt the new routine, but only a critical mass of agents. This critical mass may be anywhere from $0.1 \%$ to $100 \%$ in real life, and some agents may carry more weight than others. In general, if returns from pursuing a new strategy are positively related to the number of agents pursuing the same strategy, and if a small number of switching agents would be worse of then by following the old routine, then coordination of a critical mass of agents is necessary to attain the paretosuperior equilibrium. This coordination can be achieved by a leader creating the common belief among at critical mass of agents, than a critical mass will switch. 
Notice, however, that during the adjustment, the return may fall before it increases. This indicates a transitional crises as observed in many firms during radical change. ${ }^{9}$ To achieve adjustment without transitional crises, a larger critical mass $\boldsymbol{b}$ is required. In a variation, I drew an alternative payoff function old' for those staying with the old routine. Here they benefit from the increased productivity of those switching early. While this scenario avoids the transitional crises, paradoxically, it requires a larger critical mass $\left(\boldsymbol{a}^{\prime}=\boldsymbol{b}^{\prime}\right)$ to reach the new equilibrium. $^{10}$

Note, that the critical mass game requires less strict assumptions about agents sharing common knowledge on the structure of the game. It suffices that a critical mass of agents believes that a critical mass understands the game, and will thus switch. With evolutionary dynamics like those depicted in Figures 3 and 4, large groups are easier to coordinate. The leader thus has to create common beliefs among a large number of her employees, but does not need to fulfil the strict assumptions associated with the theoretical concept of common knowledge.

\section{Conclusions and Extensions}

ET in transition economies requires radical changes not only at the organizational level, but for each individual related to it. To induce an agent to change his behaviour, he not only needs to learn the new routines, but he has to form the belief that other agents will also change their routines in such way that his new routine will make him better off. I have argued that this kind of coordination problem can be overcome by a leader of the organization, who performs the following tasks:

- to define the strategy of the firm out of a subset of alternative transformation strategies.

${ }^{9}$ In real life situations, such a transitional crises may undermine the credibility of the leader and the announced strategy. If the structure of the game and its payoffs is not common knowledge, this can thus lead to a resistence to change, and in fact attempts to return to the original equilibrium, even though under the above assumptions the game would converge to the superior Nash equilibrium.

${ }^{10}$ The need for a critical mass in transition has recently been formally analysed by Sacco and Scarpa (2000) following a different logic. Focussing on the interdependence between firms, they model a network externality in the form of demand creation. A critical mass effect emerges if restructuring liberates resources that generate a large impact on aggregate demand and if individual firms' profitability depends heavily on GDP rather than their individual strategy. 
- to create incentives that minimize conflicts of interest among the stakeholders, i.e. the new corporate strategy becomes a Nash equilibrium of individual routines. ${ }^{11}$

- to create common beliefs about the new strategy among a critical mass of agents who will thus switch and initiate evolutionary dynamics which in turn will lead to a superior Nash-equilibrium.

This leadership challenge emerges not only in enterprise transformation. Similar dynamic coordination games emerge at several levels in transition economies (Shleifer and Treisman 1999). For instance, firms are integrated into business networks, especially if there is limited entry. They will move from the old-boy survival and rent-seeking type of networks (Huber and Worgötter 1998) to entrepreneurial networks when a critical mass of firms finds it more beneficial to leave the old networks. Also the protectionism of regions within Russia suffers from a dynamic coordination game default as individual regions try to protect their local industry through trade barriers (Broadman 1999). Most would benefit from trade liberalization, but - as in international trade - strong lobbying by local firms inhibits the liberalization. At every level, a critical mass of agents changing to the new set of routines, attitudes and business strategies is necessary to move the group as a whole to a new, better world. A leader can play a pivotal role in moving society from one stable equilibrium to another one, usually a superior one.

Further research should incorporate this crucial role of leaders. In particular, empirical studies on enterprises in transition should include vectors of personal characteristics of leadership, such as the prior experience and reputation of both the CEO and the top management team. The empirical research by Barberis et al. (1996) has pointed to the importance of managers as leaders of firms in transition, yet this needs to be taken further. Theoretical research should deepen the analysis of coordination problems in transformation processes, analysing for instance under which circumstances agents behave cooperatively and/or follow the direction proposed by a leader. Moreover, how can one create selection mechanisms that bring individuals with coordination skills into leadership positions, and how can incentives be designed for top managers to act as leaders, and in the best interest of the organization?

\section{References}

Bąk, M. and P. Kulawczuk 1997. Foreign Investment Withdrawals from Poland: Case Studies and Recommendations, mimeo, The Institute for Private Enterprise and Democracy, Warsaw.

${ }^{11}$ Recall that for most of this paper, I assumed that there are no incentive conflicts to be able to focus attention to coordination challenges as such. 
Barberis, Nicholas, Maxim Boyko, Andrei Shleifer and Natalia Tsukonova (1996): How does Privatization work? Evidence from Russian Shops, Journal of Political Economy 104, p. 764-90.

Berglöf, Erik, and Ernst-Ludwig von Thadden (1999): The Changing Corporate Governance Paradigm: Implications for Transition and Developing Countries, mimeo, Stockholm and Lausanne.

Blanchard, Oliver and Michael Kremer (1996): Disorganization, Quarterly Journal of Economics 62, p. 1091-1126.

Brada, Josef C. and Inderjit Singh, eds (1999): Corporate Governance in Central Europe: Case Studies of Firms in Transition, Armonk, N.Y.: Sharpe.

Broadman, Harry G. (1998): Reducing Structural Dominance and Entry Barriers in Russian Industry, in. H.G. Broadman, ed.: Russian Enterprise Reform, Washington, DC: World Bank.

Calvert, Randall L. (1995): The Rational Choice Theory of Social Institutions: Cooperation, Coordination, and Communication, in. Jeffrey S. Banks and Eric Hanushek, eds.: Modern Political Economy: Old Topics, New Directions. Cambridge: CUP.

Camerer, Colin and Marc Knez (1994): Creating Expectational Assets in the Laboratory: Coordination and 'Weakest-Link' Games, Strategic Management Journal 15, p. 101119 .

Carlin, Wendy, John van Reenen and Toby Wolfe (1995): Enterprise Restructuring and Dynamism in Transition Economies, Economics of Transition 3, p. 427-458.

Child, John and Andre P. Czegledy (1996): Managerial Learning in the Transformation of Eastern Europe: Some Key Issues, Organization Studies 17, p. 167-180.

Claessens, Stijn and Simeon Djankov (1998): Managers, Incentives and Corporate Performance: Evidence from the Czech Republic, mimeo, The World Bank, April.

Colman, Andrew M. (1997): Salience and Focussing in Pure Coordination Games: Journal of Economic Methodology 4, p. 61-81.

Cooper, Russel W. (1999): Coordination Games: Complementarities and Macroeconomics, Cambridge: CUP.

Cooper, R., D.Dejong, R. Forsythe and T. Ross (1994): Alternative Institutions for Resolving Coordination Problems: Experimental Evidence on Forward Induction and Preplay Communication, in: J. Friedman, ed.: Problems of Coordination in Economic Activity, Boston: Kluwer p. 129-146.

Crawford, Vincent P. 1997. Theory and Experiment in the Analysis of Strategic Interaction, in: D.M. Kreps and K.F. Wallis, eds, Advances in Economics and Econometrics: Theory and Applications. Seventh World Congress, Vol. 1, p. 206-242.

Farrell, Joseph 1988. Communication, Coordination and Nash Equilibrium, Economic Letters 27, p. 209-214.

Finkelstein, S. And D.C. Hambrick (1996): Strategic Leadership: Top Executives and their effects on organizations, St.Paul: West Publishing.

Fudenberg, D and D. Kreps 1993. Learning mixed equilibria, Games and Economic Behaviour 5, p. 320-367. 
Foss, Nicolai, 2001. Leadership, Belief and Coordination: An Explorative Discussion, Industrial and Corporate Change, forthcoming.

Gallagher, J.G. and R.S. Scott (1996): VOS Industries: Entrepreneurship in the New Russia, European Case Clearing House, case \# 396-027-1.

Geanopolous, John (1992): Common Knowledge, Journal of Economic Perspectives 6, p. 5882.

Goldberg, Itzhak and Lev Freinkman (2000): Book review of Shleifer and Tresiman (1999), Finance and Development 37, no. 3, p. 60.

Grayson, Leslie E. and Samuel E. Bodily (1996): Integration into the World Economy: Companies in Transition in the Czech Republic, Slovakia and Hungary, Laxenburg, Austria: IIASA.

Huber, Peter and Andreas Wörgötter (1998): Political Survival or Entrepreneurial Development? Observations on Russian Business Networks, in: S.S. Cohen, A. Schwartz and J. Zysman, eds.: The Tunnel at the End of the Light, A BRIE Kreisky Forum Project, University of California Berkeley.

Ireland, R. Duane and Michael A. Hitt (1999): Achieving and Maintaining Strategic Competitiveness in the 21st century: The Role of Strategic Leadership, Academy of Management Executive 13, p. 43-57.

Johnson, Simon and Gary W. Loveman (1995): Starting Over in Eastern Europe: Entreprenneurship and Economic Revival, Cambridge, MA: Harvard Business School Press.

Kim, Yong-Gwan and Joel Sobel (1995): An Evolutionary Approach to Pre-Play Communication, Econometrica 63, p. 1181-1193.

Kogut, Bruce (1996): Direct Investment, Experimentation, and Corporate Governance in Transition Economies, in: R. Frydman, C. W. Gray and A. Rapazynski (eds.): Corporate Governance in Central Europe and Russia, vol. 1, London and Budapest: Central European University Press, p. 293-332.

Kogut, Bruce and Udo Zander (2001): Did Socialism fail to Innovate? A Natural Experiment of the Two Zeiss Companies, American Journal of Sociology, forthcoming.

Lewis, D. (1969): Convention: A Philosophical Study, Cambridge, MA: HBS Press.

Lieb, Doczy, Enese E (2000): Transition to Survival: Enterprise Restructuring in Twenty East German and Hungarian Companies, Aldershot: Ashgate, forthcoming.

Matesova, Jana (1999): Veba Broumov, in: J.C. Brada and I.J. Singh, eds: Corporate Governance in Central Europe: Case Studies of Firms in Transition, Armonk, N.Y.: Sharpe.

Meyer, Klaus E. (1998): Enterprise Restructuring and Direct Foreign Investment, Journal of East-West Business 4, p. 7-28.

Monderer, Dov and Dov Samet (1989): Approximating Common Knowledge with Common Beliefs', Games and Economic Behavior 1, p. 170190.

Myerson, R. (1989): Credible Negotiation Statements and Coherent Plans, Journal of Economic Theory 48, p. 264-291. 
Mygind, Niels (1999): Enterprise Governance in Transition: A Stakeholder Perspective, Working Paper no. 29, Center for East European Studies, Copenhagen Business School, December.

Newman, Karen (2000): Organizational transformation during institutional upheaval, Academy of Management Review 25, no. 3, p. 602-619.

Newman, Karen and Stanley Nollen (1998): Radical Organizational Change, Thousand Oaks, CA: Sage.

Nellis, John (1999): Time to Rethink Privatization in Transition Economies? Washington, DC: World Bank/IFC Working Paper no. 38.

Ochs, Jack (1995): Coordination Problems, in: J.H. Kagel and A. Roth eds, Handbook of Experimental Economics, Princeton, N.J., Princeton University Press, p. 195-251.

Roland, Gerard and Theirry Verdier (1999): Transition and the Output Fall, Economics of Transition 7, no. 1, p. 28.

Sacco, Pier Luigi and Carlo Scarpa (2000): Critical Mass Effect and Restructuring in the Transition towards a Market Economy, European Economic Review 44, p. 587-608.

Shleifer, Andrew and Daniel Treisman (1999): Political Tactics and Economic Reform in Russia, Cambridge, MA: MIT Press.

Spicer, Andrew, Gerry McDermott and Bruce Kogut (2000): Entrepreneurship and Privatization in Central Europe: The Tenuous Balance between Destruction and Creation, Academy of Management Review, 25, no. 3; 630-649.

Swaan, Wim (1997): Knowledge, Transaction Costs and the Creation of Markets in PostSocialist Economies, in: P.G. Hare and J. Davis, eds: Transition to the Market Economy, Volume II, London and New York: Routledge, p. 53-76.

Rubinstein, Ariel (1989): The Electronic Mail Game: Strategic Behavior under 'Almost Common Knowledge', American Economic Review 79, p. 385-391.

Uhlenbruck, Klaus, Klaus E. Meyer and Michael Hitt (2000): Organizational Transformation in Transition Economies: Resource-based and Organizational Learning Perspectives, CEES working paper no. 35, Copenhagen Business School, June.

Vlachotsicos, Charalambos (1998): Russian Communitarianism: An Invisible Fist in the Transformation Process in Russia. Working paper no. 120, William Davidson Institute, University of Michigan Business School, January. 